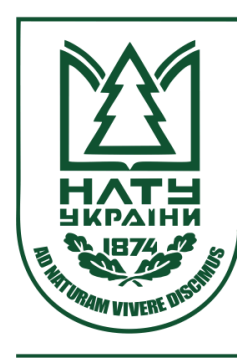

Науковий вісник НЛТУ України Scientific Bulletin of UNFU

https://nv.nltu.edu.ua

https://doi.org/10.36930/40300316

$@ \bowtie$ Correspondence author

Article received 30.05.2020 p.

Article accepted 04.06.2020 p.

S. V. Niemyi

UDC 629.621 .114

\title{
ЕНЕРГЕТИЧНІ ВИТРАТИ У ПРИВОДІ КОМПРЕСОРА ГАЛЬМІВНОЇ СИСТЕМИ АВТОМОБІЛЬНИХ ТРАНСПОРТНИХ ЗАСОБІВ
}

Визначено умови, за яких виникають найбільші енергетичні витрати під час роботи компресора автомобільного транспортного засобу (АТЗ). Розроблено методику оцінювання витрат енергії на привод компресора. Запропоновано у ролі показника експлуатаційної ефективності автомобільного компресора величину питомої приводної потужності. Показником експлуатаційної ефективності компресора, окрім надійного живлення гальмівної системи та надійності конструкції, $є$ витрати енергії для його привода. Зазначений показник безпосередньо впливає на паливну ощадливість автомобіля та опосередковано - на надійність конструктивних елементів гальмівної системи і автомобіля загалом. Метою дослідження $\epsilon$ спроба розробити методику оцінювання величини енергетичних витрат для привода компресора автомобіля 3 урахуванням умов і режимів експлуатації. Для запобігання тривалій безперервній роботі компресора і його частих вмиканням, а також для підтримання нормального тиску в системі в разі випадкових збільшень витрат повітря, у АТЗ застосовують компресори, масова продуктивність яких у 4...6 разів більша від масової витрати повітря на одне повне гальмування. Значення витрат потужності двигуна на привод компресора у будь-який момент часу знаходиться у діапазоні, мінімальне значення якого відповідає відсутності протитиску на виході компресора, а максимальне відповідає нагнітанню компресора при протитиску, рівному номінальному значенню тиску в пневмосистемі. Величина приводної потужності компресора складається із двох складових: постійної і змінної. Постійна становить витрати потужності за відсутності протитиску. Змінна залежить від умов експлуатації, тобто інтенсивності гальмувань, що визначають тривалість роботи компресора під повним навантаженням. Для мінімізації витрат потужності двигуна для привода компресора, важливою є його експлуатаційна ефективність. Показником експлуатаційної ефективності компресора доцільно прийняти величину його питомої потужності привода відношення приводної потужності компресора до його продуктивності. Питома потужність привода компресорів одного і того самого діапазону потужності може значно відрізнятися - практично у півтора раза. Це пояснюють значною різницею механічних ККД компресорів. Під час вибору компресора для живлення пневмосистеми АТЗ, окрім необхідної продуктивності, потрібно враховувати і питому потужність привода для зменшення енерговитрат двигуна для привода компресора. Результати роботи: визначено умови, за яких виникають найбільші енергетичні витрати під час роботи компресора АТЗ; розроблено методику оцінювання витрат енергії двигуна АТЗ для привода компресора; показником експлуатаційної ефективності автомобільного компресора доцільно прийняти величину питомої потужності привода.

Ключові слова: робочі характеристики компресора; витрати енергії для привода; витрати потужності двигуна; продуктивність компресора; питома потужність привода; допоміжні агрегати.

\section{Вступ}

Основним напрямком вдосконалення конструкцій автомобілів і автобусів, а також спеціалізованих транспортних засобів, зокрема лісових машин є зменшення витрати палива і безпека експлуатації. Важливим складником конструкції АТЗ, що визначає рівень його експлуатаційної ефективності, є гальмівна система й енергетичне джерело іï функціонування - пневмокомпресор (далі за текстом - компресор). Показником експлуатаційної ефективності компресора, окрім надійного живлення гальмівної системи та надійності конструкції, $є$ витрати енергії для його привода. Цей показник безпосередньо впливає на паливну ощадливість автомобіля та опосередковано - на надійність конструктивних елементів гальмівної системи і АТЗ загалом.
Об'єктом дослідження є компресори АТЗ та їх робочі й енергетичні характеристики.

Предметом дослідження є методи і засоби, які дадуть змогу визначити енергетичні витрати у приводі компресора гальмівної системи автомобільних транспортних засобів з урахуванням умов i режимів їх експлуатації.

Мета дослідження полягає в обгрунтуванні методики оцінювання енергетичних витрат для привода компресора АТЗ з урахуванням умов і режимів експлуатації.

Завданням дослідження є аналіз чинників, які впливають на енергетичне споживання компресорів, що дасть змогу визначити характерні режими експлуатації компресорів та на іiї підставі сформувати методику вибору компресорів з мінімальним енергоспоживанням на стадії проектування АТЗ.

\section{Інформація про автора:}

Нємий Степан Володимирович, канд. техн. наук, доцент, кафедра експлуатації та ремонту автомобільної техніки. Email: sniemyj@ukr.net

Цитування за ДСтУ: Нємий С. В. Енергетичні витрати у приводі компресора гальмівної системи автомобільних транспортних засобів. Науковий вісник НЛтУ України. 2020, т. 30, № 3. С. 89-92.

Citation APA: Niemyi, S. V. (2020). The energy consumption in the compressor drive of the car braking system. Scientific Bulletin of UNFU, 30(3), 89-92. https://doi.org/10.36930/40300316 
Наукова новизна дослідження полягає у тому, що було розроблено методику розрахунку споживання компресором витрат енергії двигуна та вибору критерію й показника мінімального енергоспоживання під час вибору моделі компресора у процесі проектування АТЗ.

Практична значущість отриманих результатів дослідження полягає у тому, що розроблену методику можна використати для мінімізації витрат потужності двигуна для привода компресора, що є показником експлуатаційної ефективності компресора - відношення приводної потужності компресора до його продуктивності.

Аналіз літературних джерел. У наявних публікаціях, наприклад $[1,2,3,4]$, проблему енергетичних витрат для привода компресора не відображено. У них обмежуються тільки визначенням необхідної продуктивності без розрахунку потужності двигуна, що витрачається для привода компресора. Методику цього розрахунку на сьогодні у публікаціях не відображено. У розрахунках корективи потужності двигунів здійснюються, практично, тільки з урахуванням ККД механічної трансмісії, без урахування витрат для привода допоміжних агрегатів, зокрема компресора $[1,2]$. Через це практично не розглядають можливості підвищення експлуатаційної ефективності АТЗ за рахунок зменшення витрат енергії двигуна на привод компресора, поряд 3 іншими допоміжними агрегатами автомобіля. Окрім цього, знижується точність розрахунків експлуатаційних витрат палива та енергетичних показників експлуатаційної ефективності АТЗ. Огляд наукових публікацій у зарубіжних виданнях показав, що цю проблематику не розглядають. Публікації обмежуються фірмовими каталогами 3 геометричними параметрами i робочими характеристиками компресорів.

Виклад основного матеріалу. Потужність, споживану компресором, визначають за формулою [3]

$$
N_{\kappa}=\frac{N_{\text {пол }}}{\eta_{M} \eta_{n p}}
$$

де: $N_{\text {пол }}$ - потужність політропного стискання; $\eta_{м}$ i $\eta_{n p}-$ відповідно, механічний ККД компресора і його привода.

$$
N_{\text {пол }}=\frac{n}{n-1} P_{1} Q_{\kappa}\left[\left(\frac{P_{2}}{P_{1}}\right)^{\frac{n-1}{n}}-1\right] \text {, }
$$

де: $n$ - показник політропи; $Q_{k}-$ продуктивність компресора; $P_{1}$ і $P_{2}-$ відповідно, значення тиску повітря на початку і в кінці робочого ходу поршня компресора.

$$
Q_{\kappa}=V_{\kappa}\left(a-b P_{\kappa}\right) \omega_{\kappa},
$$

де: $V_{\kappa}$ - робочий об'єм компресора; $a, b$ - постійні коефіцієнти; $P_{\kappa}-$ протитиск на виході із компресора (тиск у ресиверах АТЗ); $\omega_{k}=\pi n_{\kappa} / 30-$ кутова частота обертання вала компресора; $n_{\kappa}$ - частота обертання вала компресора, $\mathrm{xB}^{-1}$.

Аналізуючи формули (1)-(3), можна припустити, за постійного значення показника політропи $n$, що для будь-якого значення тиску у ресиверах АТЗ потужність, споживану компресором, $з$ достатньою точністю, можна виразити лінійною залежністю

$$
N_{\kappa}=A n_{\kappa},
$$

де $A$ - постійна, для кожного значення тиску у ресиверах АТЗ, величина.

Виходячи із залежності (4), маючи значення $N_{\kappa}$ при $n_{\kappa}$ і протитиску $P_{k}$, потужність споживану компресором
$N_{\kappa i}$ за будь-яких інших обертів $n_{\kappa i}$ У робочому діапазоні їх зміни можна визначити за формулою

$$
N_{\kappa i}=\frac{N_{\kappa} n_{\kappa i}}{n_{\kappa}} .
$$

Залежність потужності $N_{\kappa}$ і продуктивності $Q_{\kappa}$ від частоти обертів при протитиску $P_{\kappa}$ (бар), споживаної компресором, наведено на рис. 1 і 2. Для прикладу, наведено характеристики компресора моделі 52 254/C CSONKA (KNORR-BREMSE, Угорщина).

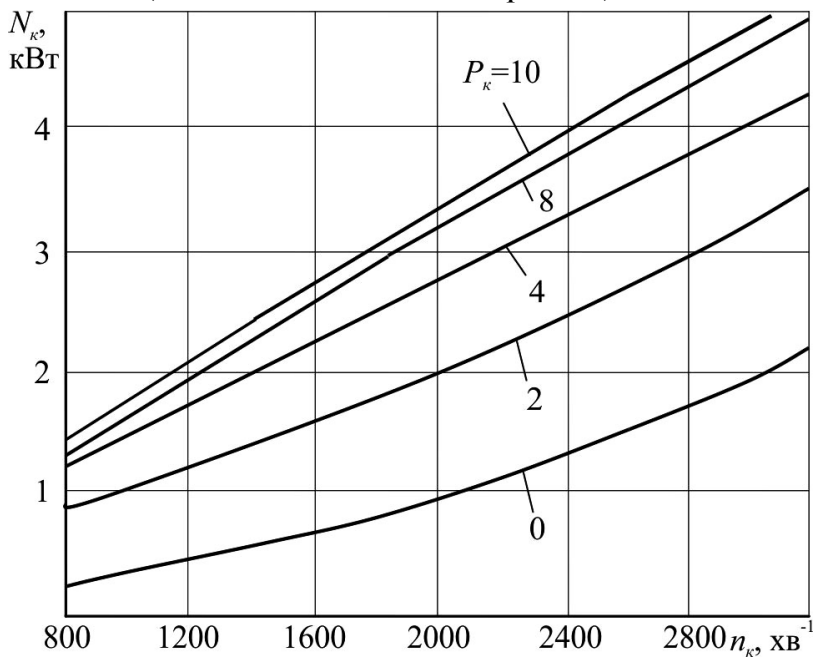

Рис. 1. Залежність потужності, споживаної компресором, від частоти обертів його вала при протитиску $P_{\kappa}$ (бар)

Для запобігання тривалій безперервній роботі компресора і його частим вмиканням, а також для підтримання нормального тиску в системі в разі випадкових збільшень витрат повітря, у АТЗ застосовують компресори, масова продуктивність $m_{\kappa}$ яких у 4...6 разів більша від масової витрати повітря на одне повне гальмування [3].

Маса повітря, що витрачається на одне повне гальмування:

$$
m_{2}=\frac{P_{o} V_{o}}{R T},
$$

де: $P_{o}$ - тиск у виконавчих органах під час гальмування; $V_{o}$ - об'єм виконавчих органів гальм; $R$ - універсальна газова стала; $T$ - абсолютна температура повітря.

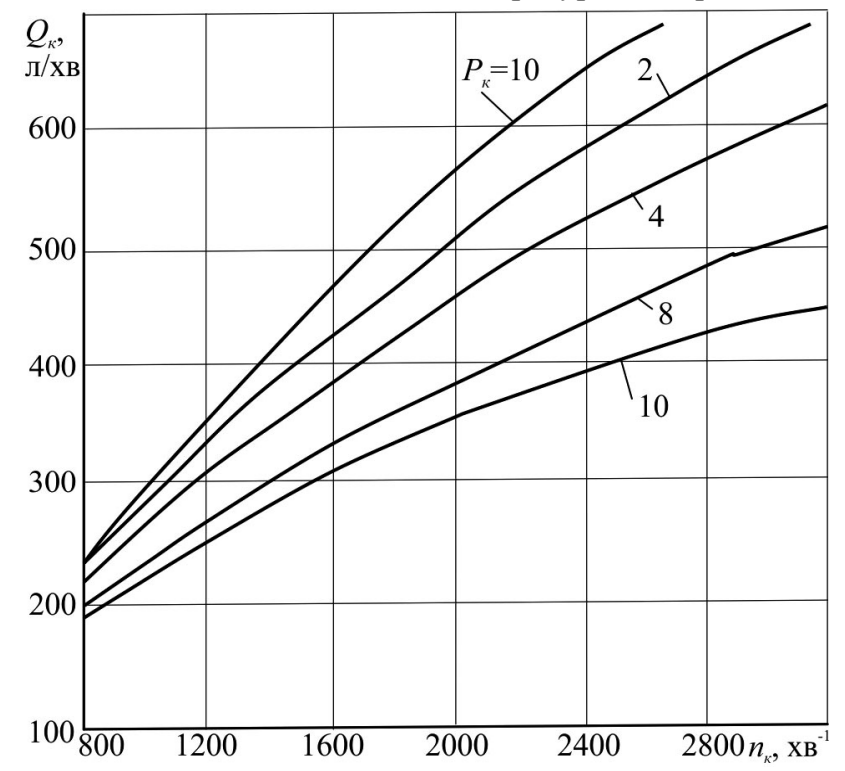

Рис. 2. Залежність продуктивності компресора від частоти обертів його вала при протитиску $\mathrm{P}_{\text {к }}$ (бар) 
Необхідну на одне гальмування подачу компресора визначають за формулою [3]:

$$
Q_{n 2}=\frac{m_{2} R T}{P_{B x}}=\frac{P_{o} V_{o}}{P_{6 x}},
$$

де $P_{6 x}$ - тиск повітря на вході у компресор, який дорівнює $0,1 \mathrm{MПа.}$

Як бачимо у формулах (2) i (3) та на рис. 1, експлуатаційні витрати потужності на привод компресора залежать від двох факторів: від протитиску в пневмосистемі АТЗ і частоти обертів вала компресора, який кінематично зв'язаний з колінчастим валом двигуна із певним передатним відношенням.

Протитиск у пневмосистемі АТЗ залежить від витрат повітря на гальмування і привод дверей (в автобуcax). Витрати повітря у пневмосистемі залежать від кількості гальмувань (на 1 км пробігу), тобто від умов експлуатації. У русі по міжміському шосе кількість гальмувань та зупинень на 1 км пробігу мінімальні, а в умовах міської експлуатації - максимальні.

Зважаючи на особливості швидкісного діапазону роботи двигуна [5], розбивши діапазон його обертів на ряд однакових елементарних інтервалів $\Delta n$, еквівалентне (середнє) значення приводної потужності компресоpa, за певного значення протитиску у системі, можна визначити за формулою

$$
N_{k e}=N_{k x} \Delta t_{x}+\sum_{i=1}^{k} N_{k i} \Delta t_{i}
$$

де: $N_{\kappa x}$ - приводна потужність компресора, що відповідає частоті марних обертів вала двигуна; $N_{\kappa i}-$ приводна потужність компресора, що відповідає обертам вала двигуна у середині певного елементарного інтервалу; $n_{\partial x}$ - частота обертання колінчастого вала двигуна на марному ходу; $\Delta t_{x}-$ відносний час роботи двигуна на марному ходу; $k$ - кількість елементарних інтервалів у швидкісному діапазоні $n_{\partial x}-n_{\text {дмах }} ; n_{\partial i}-$ частота обертання колінчастого вала двигуна у середині певного елементарного інтервалу; $\Delta t_{i}-$ відносний час роботи двигуна у певному елементарному інтервалі.

Суть розрахунку за формулою (8) наведено на рис. 3. Частоту обертання вала компресора за статистичним розподілом частоти обертання вала двигуна (функція розподілу $F(n)$ ), при цьому, визначають за формулою

$$
n_{\kappa}=n_{\partial} u_{\kappa},
$$

де: $n_{\partial}$ - частота обертів двигуна; $u_{\kappa}-$ передатне відношення привода компресора.

Як бачимо на рис. 1, значення витрат потужності двигуна на привод компресора у будь-який момент часу знаходиться у діапазоні, мінімальне значення якого відповідає відсутності протитиску на виході компресора, а максимальне відповідає нагнітанню компресора при протитиску, рівному номінальному значенню тиску в пневмосистемі (тиск спрацювання регулятора).

Регулятор тиску від'єднує циліндри компресора від пневмосистеми в разі досягнення верхнього (номінального) значення тиску у пневмосистемі. Зі зниженням тиску у ресиверах АТЗ до нижньої межі налаштування регулятора, останній з'єднує нагнітальний тракт компресора із пневмосистемою і тиск у ній піднімається до номінального значення. Номінальний тиск у пневмосистемі гальм сучасних автомобілів становить $0,75 \ldots$ 0,8 МПа $[1,4]$. Нижня межа тиску, за якої регулятор забезпечує роботу компресора на нагнітання, становить
0,6...0,65 МПа [1, 4]. Отже, у діапазоні 1,0...0,8 від номінального значення тиску у пневмосистемі компресор працює на нагнітання із повним споживанням приводної потужності. При цьому варто зауважити, що за вказаних значень тиску різниця між споживаною потужністю за номінального тиску і нижньою межею тиску, за будь-якої частоти обертання вала компресора, порівняно незначна, наприклад, згідно з даними рис. 1, не перевищує 5...9\%. Отже, для розрахунків можна прийняти значення споживаної потужності компресора при протитиску, що становить 0,9 величини номінального тиску у пневмосистемі гальм АТЗ.

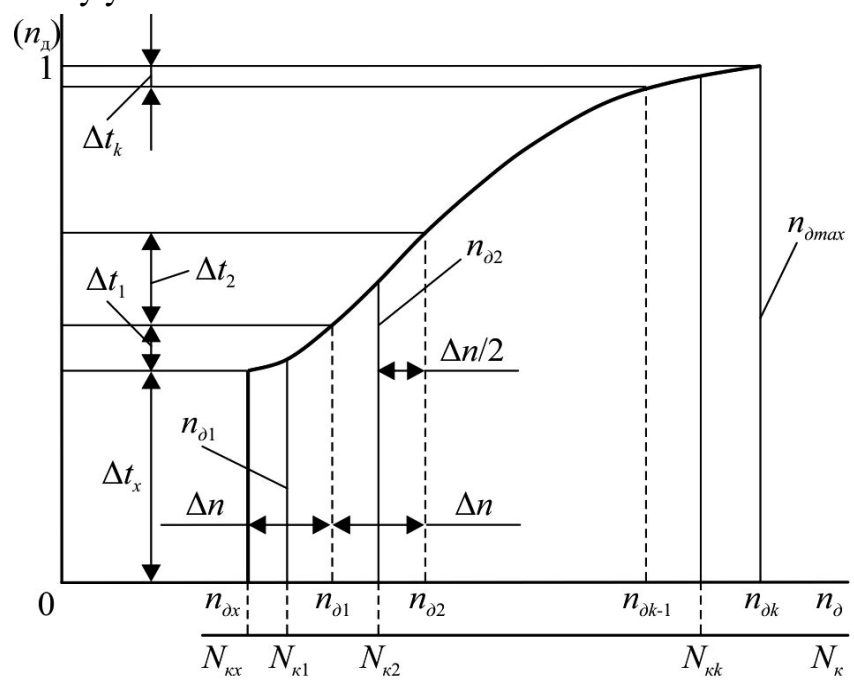

Рис. 3. Розрахунок середнього значення приводної потужності компресора за статистичним розподілом частоти обертання вала двигуна

Як випливає із наведеного, величина приводної потужності компресора складається із двох складових: постійної і змінної. Постійна становить витрати потужності за відсутності протитиску (наприклад, на рис. 1 крива при $\left.P_{\kappa}=0\right)$. Змінна залежить від умов експлуатації, тобто інтенсивності гальмувань, що визначають тривалість роботи компресора під повним навантаженням.

Під час вибору моделі компресора пневмосистеми АТЗ, для мінімізації витрат потужності двигуна для його привода важливою є експлуатаційна ефективність компресора. Показником експлуатаційної ефективності доцільно прийняти величину питомої потужності привода:

$$
N_{\text {кпит }}=N_{\kappa} / Q_{\kappa} \rightarrow \min .
$$

Нагадаємо, що питома потужність - це відношення потужності двигуна до його маси або іншого параметру. Потужність поршневого двигуна, віднесена до літражу двигуна, називається літровою потужністю; віднесена до сумарної площі його поршнів - поршневою потужністю і так далі. Зростання питомої потужності досягається застосуванням легких сплавів, вдосконаленням конструкцій та форсуванням (збільшенням швидкохідності та ступеня стискування, використанням наддуву тощо).

Для порівняння, у таблиці наведено показники питомої потужності привода деяких моделей компресорів при $P_{\kappa}=0,7 \mathrm{MПа} \mathrm{і} n_{\kappa}=2000 \mathrm{xB}^{-1}[3,6]$.

Згідно з даними таблиці, питома потужність привода компресорів одного і того самого діапазону потужності може значно відрізнятися - практично у півтора раза. Це пояснюють тільки одним - значною різницею механічних ККД компресорів $\eta_{s}$, тобто їх технічним рівнем. Отже, під час вибору компресора для живлення пнев- 
мосистеми АТЗ, окрім необхідної продуктивності, потрібно враховувати і питому потужність привода для змен-

Таблиця. Питома потужність привода деяких моделей компресорів

\begin{tabular}{|c|c|c|c|c|}
\hline Модель & Виробник & $\begin{array}{c}\text { Приводна потужність } \\
N_{\kappa}, \text { кВт } \\
\end{array}$ & $\begin{array}{c}\text { Продуктивність } Q_{k}, \\
\text { л/хв }\end{array}$ & $\begin{array}{c}\text { Питома приводна по- } \\
\text { тужність } N_{\text {кmиm }}, \mathrm{BT} \cdot \text { хв/л }\end{array}$ \\
\hline 3ІЛ-130 & ЗІЛ, РФ & 2,5 & 220 & 11,36 \\
\hline A29.1400M & АК "АДВІС", Україна & 3,2 & 290 & 11,03 \\
\hline $161.3509015-20$ & AURIDA, Литва & 2,4 & 282 & 8,51 \\
\hline $52254 / \mathrm{C}$ & CSONKA, Угорщина & 3,0 & 406 & 7,39 \\
\hline KNORR 61.329 & KNORR-BREMSE, Німеччина & 2,8 & 380 & 7,37 \\
\hline
\end{tabular}

\section{Висновки:}

1. Визначено умови, за яких виникають найбільші енергетичні витрати під час роботи компресора АТЗ.

2. Розроблено методику оцінювання витрат енергії двигуна АТЗ для привода компресора.

3. Показником експлуатаційної ефективності автомобільного компресора доцільно прийняти величину питомої потужності привода.

\section{Reference}

1. BOSCH. (2002). Avtomobilnyi spravochnik. (Trans. from English). (1st ed.). Moscow: ZAO KZhI "Za rulem", 896 p. [In Russian].
2. Grishkevich, A. I. (1986). Avtomobili: Teoriia. Minsk: Higher. school, 207 p. [In Russian].

3. Kozlovskii, Iu. A., Bogdan, N. V., \& Romanchik, E. A. (1990). Avtotraktornye kompressory. Khmelnitckii, 70 p. [In Russian].

4. Mikhailovskii, E. V., Serebriakov, K. B., \& Tur, E. Ia. (1985). Ustroistvo avtomobilia. Textbook. (5th ed. add. and revised). Moscow: Mashinostroenie, 352 p. [In Russian].

5. Niemyi, S. V. (2012). Statystychne determinuvannia shvydkisnoho rezhymu dvyhuniv avtobusiv. Bulletin of the National University "Lviv Polytechnic". Series: Dynamics, strength and design of machines and devices, 730, 119-124. [In Ukrainian].

6. Vysokoproizvoditelnye kompressory. (2001). Informatciia o produktcii. KNORR-BREMSE. Systeme für Nutzfahrzeuge, 4 p. [In Russian].

S. V. Niemyi

Lviv Polytechnic National University, Lviv, Ukraine

\section{THE ENERGY CONSUMPTION IN THE COMPRESSOR DRIVE OF THE CAR BRAKING SYSTEM}

The paper presents the results of the research of energy consumption in the car braking system compressor drive. The authors have determined the conditions under which the highest energy consumption occurs when operating the compressor of the vehicle. In the course of research the evaluation methodology of energy consumption of a compressor drive was designed. The value of specific power is proposed as an indicator of the operational efficiency of an automobile compressor. The in-use performance ratio of the compressor is energy consumption on its drive except the reliable supply of the braking system and the reliability of the design. This indicator directly affects the fuel economy of the vehicle and influences indirectly the reliability of the structural elements of the braking system and the car as a whole. The purpose of this work is to develop a technique for estimating the magnitude of energy costs for the drive of compressor, taking into account conditions and operating modes. In order to prevent long continuous operation of the compressor and frequent start-ups as well as to maintain normal pressure in the system with an accidental increase in air flow, vehicles use compressors which mass capacity is from 4 to 6 times greater than the mass flow rate of air for one complete brake. The values of the power consumption of the engine at the compressor drive at any time is in the range, the minimum value of which corresponds to the lack of backpressure at the outlet of the compressor and the maximum corresponds to the discharge of the compressor at the backpressure equal to the nominal value of pressure in the pneumatic system. The value of the drive power of the compressor consists of two components such as constant and variable. The constant is the cost of power in the absence of backpressure. The variable one depends on the operating conditions, to wit the intensity of the brakes that determine the duration of operation of the compressor under full load. The operational capacity is an important factor for minimization of power consumption of the engine to the compressor drive. It is advisable to take the value of its specific drive power as an indicator of the operational efficiency of the compressor - the ratio of the compressor drive power to its productivity. The specific drive power of compressors of the same power range may differ substantially almost one and a half time. It explains a big difference of mechanical efficiency of compressors. When choosing a compressor for supplying a pneumatic system of the vehicle in addition to the required productivity, it is necessary to consider the specific drive power to reduce the energy consumption of the engine compressor drive. To summarize, we have come to the following conclusions. Firstly, the conditions under which the highest energy costs occur when operating the compressor of a motor vehicle were determined. Secondly, the evaluation methodology of consumption energy of the compressor drive was designed. Finally, the authors suggest taking the value of its specific drive power as an indicator of the operational efficiency of the compressor.

Keywords: the working characteristics of compressor; the energy consumption for drive; engine power consumption; the productivity of the compressor; the operational efficiency of the compressor; the auxiliary aggregates. 